\title{
Large-scale Evolutionary Knowledge Network and Multiple Integration of University Ideological and Political Education Resources Based on Inference Algorithm
}

\author{
Chunyan Ma \\ Sport and art department, Xi'an Physical Education University, Xi'an 710068, \\ Shaanxi, China \\ *m15353684310_1@163.com
}

\begin{abstract}
In the era of big data network, the data is no longer just a simple collection of objects; it contains a wealth of rich, complex, related knowledge. The effective use of the network big data value of the main task is not only to get more and more data, but also need to dig more useful knowledge from the existing data. In this paper, the author analyzes the multiple integration mechanism of ideological and political education resources, by using a KP-LIM inference method on association. Based on empirical analysis, we construct the performance evaluation system of ideological and political education; the result shows that first-class index includes policy implementation (0.25), subject of education (0.15), ideological and political education process (0.2), information system construction (0.15) and environment construction (0.25). College should construct implementation system allround education of ideological and political education, in order to achieve the multiple integration effect.
\end{abstract}

Keywords: Knowledge network, political education, network data, inference algorithm

\section{Introduction}

With the arrival of the era of big data network spatio-temporal information is more and more abundant knowledge in the network, the description model to characterize spatial and temporal information lack of knowledge of the existing network[1]. Research shows that the use of network knowledge in spatio-temporal information and correlation, can improve the accuracy of the correlation between knowledge reasoning in the network. The era of big data networks, the data is no longer is just a simple collection of objects; its behind contains a large number of rich, complex and related knowledge[2]. The current network data is widely available, not just from the extracted knowledge. The main task of the effective use of the network is not only the value of big data is getting more and more data mining, also need more useful the knowledge from the existing data, to construct the knowledge base, to make full use of knowledge, so knowledge based on large-scale network, the construction of knowledge base is a popular research direction. Based on a large-scale knowledge base related reasoning is from the mass of information mining knowledge to achieve the growth of knowledge base is one of the effective means and the main purpose is implicit in the use of existing large-scale knowledge inference network or forecast knowledge network relationship[3-4]. At present, relevance reasoning has been in personalized recommendation, community discovery; knowledge quiz has been widely applied.

Big ideological and political education is the rise in recent years a research trend, it is refers to the use of the system on the concept of the organic integration of the elements of school education will be, by the staff of ideological education, educational content, educational environment, teaching practice in all aspects of the overall reform and system 
optimization, to construct implementation system all-round education of Ideological and political education of college students, to achieve the ideological and political education in Colleges and universities in maximum force[5]. Bear ideological and political course full-time teachers teaching theory, students counselors responsible for students' daily conduct and work style of school related administration personnel will exert a subtle influence on the formation of the students, the school teacher appointment is combined with the school's own characteristics, training objectives to employ the related fields of experts and scholars, these people can deliver social frontiers of theoretical knowledge and practical content for college students[6-7]. In addition to the integration of teachers, the quality of teachers to improve the quality of College Ideological and political education is also an important part of the resources. Because the educators in the process of education in the leading role of their quality, the direct impact on the effect of Ideological and political education[8]. At present, with the development of science and technology, the quality of teachers, in addition to enhance their own knowledge and quality, the quality of their own, but also to improve the quality of their own innovation. Teachers can make use of scientific and technological means, network resources, and combine the ideological characteristics of college students, innovative ideological and political education of the specific ways and means to improve the ideological and political education of College students.

\section{Evolutionary Knowledge Network Model}

\subsection{Evolution of Knowledge Networks}

Studies have shown that in relevance reasoning containing time information in heterogeneous networks; consider time information reasoning result than the one without considering time information to get better results. Similarly, by the relevant research work confirmed, add the spatial information will bring greater improvement on heterogeneous information network association inference. Fusion of the spatial information of relevance reasoning can get better reasoning results, but in the study only considered the association between an entity type reasoning, not heterogeneous information networks. At present, based on the heterogeneous information network and of temporal information in the network to be use associative inference related research is rarely.

Evolutionary knowledge network is a heterogeneous evolution of multiple graphs, and the nodes and edges in the graph both contain temporal and spatial information:

$$
G_{T, S}=(V, E, \phi, \varphi, \theta, \tau, \lambda, \eta)
$$

Where $\mathrm{V}$ is the set of nodes in the network knowledge evolution; e to the set of edges, it said the specific form is a 3-tuple $(U, V, R)$, where $u, v \in V, r \in R$, where $R$ is the set of edges of all types. $\mathrm{A} \rightarrow \mathrm{V}$ is a function of the node type, which allows each node to pass the calculation function. $\mathrm{E} \rightarrow \mathrm{R}$ means in the edge set in one side are calculated as a function and per entity of up $|\mathrm{R}|$ side; $\theta$ represents the edges in the graph, the time attribute information to describe an edge and the existence of time information.

In the model of evolution of knowledge network, we recorded the graph nodes and edges of the temporal and spatial information. Information of time here is a series of discrete time stamp, spatial information is a series of discrete geographic location information. The evolution of knowledge network evolution mainly reflected in can be produced by network aware of new changes to his own, the discovery of new knowledge, and to achieve self-renewal. Nodes and edges in the network have the time stamp information; they will change with the change of time 


\subsection{Link Extension Mode}

We propose the evolution based on the knowledge network, this paper focuses on the research of related reasoning problems on the network. The main purpose of relevance reasoning is that the use of existing knowledge as a basis for reasoning of a new relationship between two possible entities. Here we do not only relate reasoning to infer new edges, but also type this side of the main ideas. The reasoning is: firstly, construct all possible link extension mode; then set up a model of mixed knapsack problem, each model as a knapsack problem to select the items; by solving the knapsack problem, select a significance for correlation matching in reasoning mode; in using these models, infer new relationships.

Firstly introduces the evolution of knowledge network link extendable (Le) model is defined, referred to as Le mode. Due to the nodes in the network number and calculation complexity is larger and the relevance of the modest improvement. Suppose $A{ }^{\prime}=\{$ author $(\mathrm{Au})$, paper $(\mathrm{P})\}, \mathrm{R}{ }^{\prime}=\{$ write $(\mathrm{W})$, cite $(\mathrm{c})\}$, if in the sub network point set for $\mathrm{V}^{\prime}=\left\{\mathrm{V}_{1}\right.$ $(\mathrm{Au})$ and $\left.\mathrm{V}_{2}(\mathrm{P}), \mathrm{V}_{3}(\mathrm{AU})\right\}$, The edge set $\mathrm{E}^{\prime}=\left\{\mathrm{C}\left(\mathrm{V}_{1}, \mathrm{~V}_{2}\right)\right.$, w $\left.\left(\mathrm{V}_{3}, \mathrm{~V}_{2}\right), \mathrm{C}\left(\mathrm{V}_{1}, \mathrm{~V}_{3}\right)\right\}$, The LE pattern is represented by Figure 1 (a); Similarly, if the sub network for $V^{\prime}=\left\{V_{1}(P)\right.$ and $V_{2}$ (AU), $\left.\mathrm{V}_{3}(\mathrm{P})\right\}, \mathrm{E}^{\prime}=\left\{\mathrm{w}\left(\mathrm{V}_{2}, \mathrm{~V}_{1}\right), \mathrm{C}\left(\mathrm{V}_{2}, \mathrm{~V}_{3}\right), \mathrm{C}\left(\mathrm{V}_{1}, \mathrm{~V}_{3}\right)\right\}$, Then the LE model can be described as Figure 1 (b)

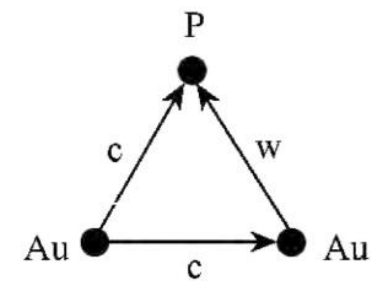

(a) First example

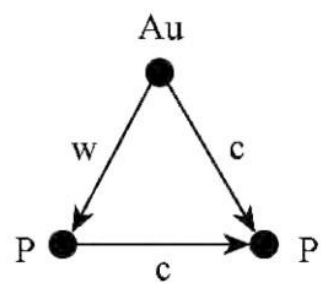

(b) Second example

\section{Figure 1. Examples for LE-Patterns}

In the real evolutionary knowledge network, all the sub networks that meet the requirements of the LE model are called the LE model, for example Figure 2.

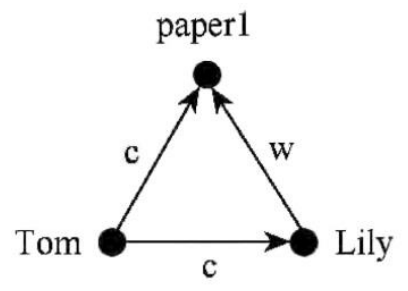

(a) First instance

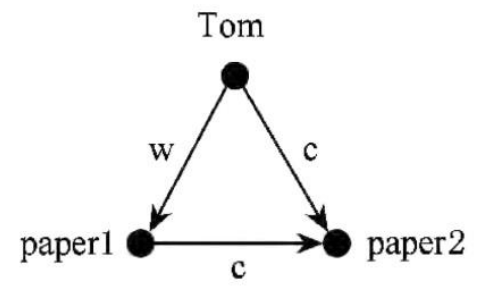

(b) Second instance

\section{Figure 2. LE-Patterns Instances}

For the definition of different Le mode we can find its corresponding examples, and for the same Le mode can have a number of different examples. In relevance reasoning, we need le mode decomposition, make it can be used to implement a new Le mode of relevance reasoning. Such as Figure 2 shows a Le mode, we can the dismantling will be divided into three interrelated inference of new model. 


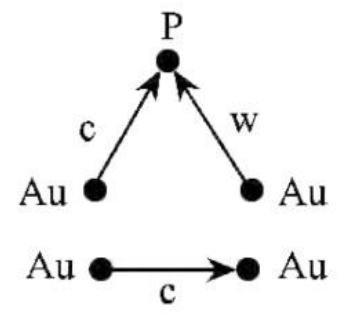

(a) First pattern

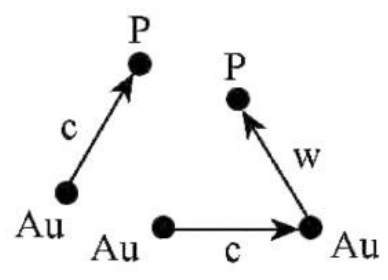

(b) Second pattern

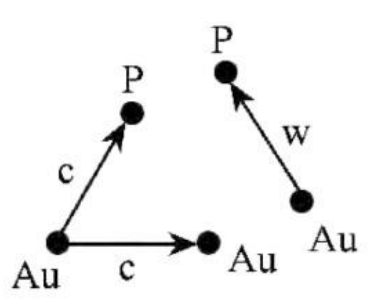

(c) Third pattern

Figure 3. LE-Patterns for Link Prediction

\subsection{Algorithm and Analysis}

The realization process of relevance reasoning can be divided into the following 3 steps: 1) structure may exist in the LE mode. The known evolution of knowledge network $G_{T, S}$, all types on the side, and any combination of 3 types of edges can constitute a candidate LE mode.2) mode choice knapsack problem. All over the map, find all instances of different modes, the calculation of different modes of Weight and Value, by solving the problem of mixed bag to choose a meaningful LE model. 3) the selected model is used to match the inference results in the network, and the implementation of the related inference algorithm is given in the following algorithm.

Algorithm 1. Association reasoning based on link extension pattern

Input: evolutionary knowledge network $\mathrm{G}_{\mathrm{T}, \mathrm{S}}$, the entity to be reasoning on the collection $\left\{\left(\mathrm{n}, \mathrm{n}^{\prime}\right)_{1},\left(\mathrm{n}, \mathrm{n}^{\prime}\right)_{2}, \ldots\left(\mathrm{n}, \mathrm{n}^{\prime}\right)_{\mathrm{k}}\right)$;

Output: reasoning out of the relationship set result.

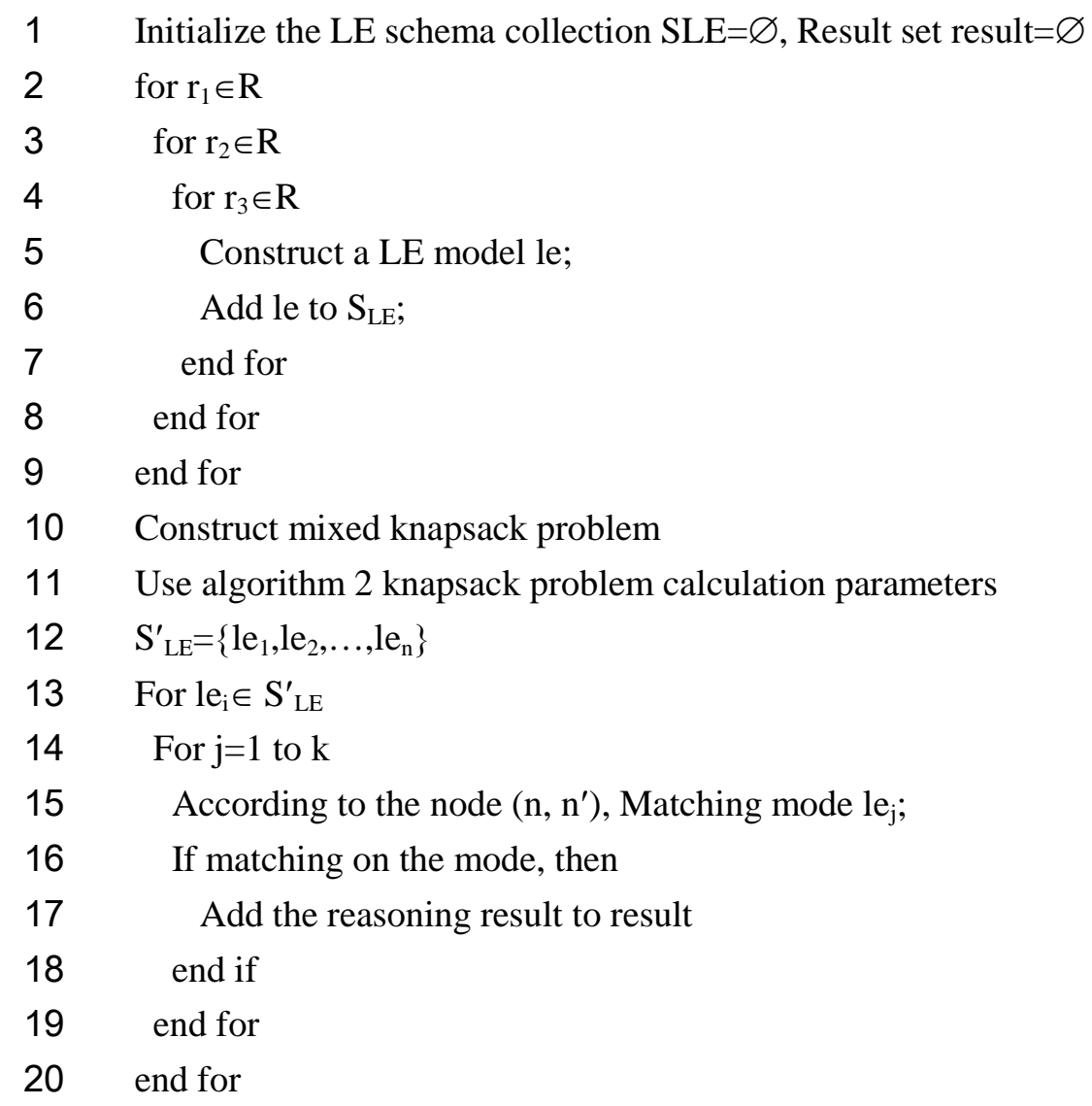


Through experiments of comparison of three aspects: 1) comparison between KPLIM and logistic and $\mathrm{CN}$ method related reasoning accuracy; 2) evolution of knowledge network and traditional heterogeneous information network; 3) KPLIM algorithm for performance test of the adaptability of the big data

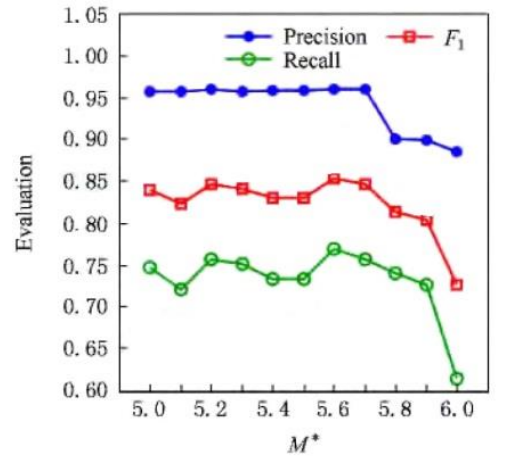

(a) Performance when $M=6$

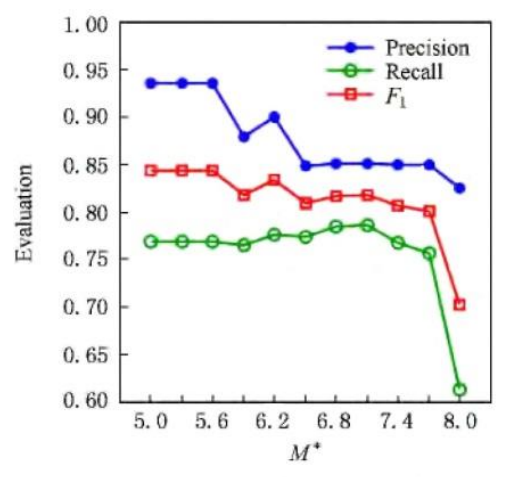

(c) Performance when $M=8$

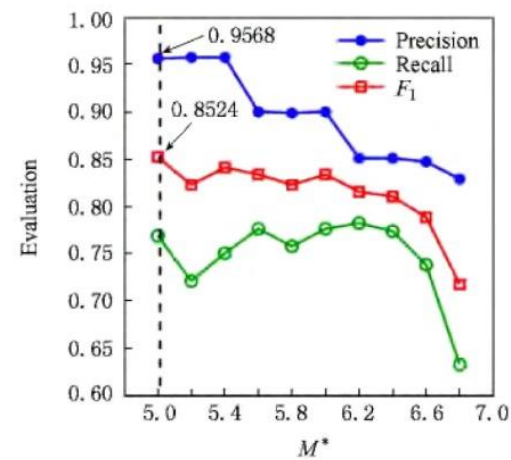

(b) Performance when $M=7$

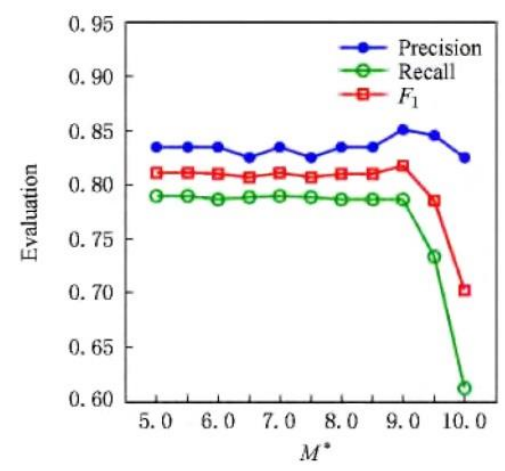

(d) Performance when $M=10$

Figure 4. Parameter Tuning on the Scholar Network

\section{Ideological and Political Education Model}

\subsection{Goals of Ideological and Political Education}

Ideological and political education goals to their ideological and political education on the basis of social change and economic development, in the scientific prediction based on, through the ideological and political education to college students' Ideological and moral behavior habit in a certain period to reach the expected effect. Ideological and political education of college students reflects the essence of Ideological and political education, but also reflects the ideological and political education of college students to study the focus of the study. Through college students' Ideological and political activities in the joint efforts of teachers and students can be achieved. In the course of the implementation of Ideological and political education of college students, the role of Ideological and political education in the course of the implementation of education is different. The implementation of the subject is teacher and student workers, responsible for the formulation and implementation of Ideological and political education goal, these people in the target implementation process is in a dominant position, so to the ideological and political objectives ultimately will have a relatively large impact. The students are the object of the implementation of the target, in the course of the target in the middle of the passive position. But the students have a subjective initiative, through the play of their 
subjective initiative, and actively participate in the process of implementation of the objectives, so that ideological and political education goals can be effectively achieved.

Student's ideological and political education goal has a certain time scale and spatial domain two dimensions, that is, subject to the existing subjective and objective conditions. Different objective historical conditions, different length of time and different coverage, the value and significance of Ideological and political education goals are not the same. So the goal of Ideological and political education of college students should conform to the objective requirements of social, economic and cultural development. Third, the goal of Ideological and political education of college students should be related to the content and methods of Ideological and political education of college students. Ideological and political education goal indicates that the ideological and political education activities and the future development direction of college students, the ideological and political education content, while ideological and political education content and in turn reflects the ideological and political education objectives.

\subsection{Guiding Principles}

The guiding principle of the ideological and political education mode is the basic principle to follow in the construction, implementation and implementation of Ideological and political education. It reflects the development direction of education reform, especially the basic law of Ideological and political education, and determines the impact of the ideological and political education model implementation and system construction. Strict adherence to these basic principles, to grasp the law of Ideological and political education, to overcome the subjective and arbitrary, to achieve the effectiveness of education is of great significance.

1) Seeking truth: the ideological and political education is the embodiment of the basic law of Ideological and political education. The combination of theory with practice is the principle that we should follow. Thought political education in the theory and practice of combining, the meaning of two aspects, one is commonly referred to as the theory of education cannot be separated from the society and people's ideological and practical; the second is refers to in education should pay attention to the education of the theory, to enhance people's awareness of the ability, but also attach importance to the student good morals practice education.

2) People oriented: "people-oriented" is the core values of Scientific Outlook on Development. Government in the measure of social development not only to pay attention to economic growth and social welfare increment basic aspects, but also to give priority to social development and human welfare and human dignity, put the development of people in the development of the central location. In the construction of student ideological and political education, all educators must truly understand the "student oriented" fundamental principles,

3) Diversification of resources integration: thought political education is a systematic project, is a systems involving both inside and outside the classroom and school factors inside and outside the complex, open, not a single factor, closed and simple system. Therefore in students' Ideological and political education mode in, in order to truly achieve the purpose of educating people, effectively improve the ideological and political education, educators should enable various resources and rational optimization, make the combination of the elements related to reach the best state, to maximize performance. 


\section{Empirical Analysis}

\subsection{Construction of Evaluation Index System}

Ideological and political education evaluation index system through constant evolution, in recent years identified as: on education evaluation index, evaluation index of the educated, to the process of education evaluation index, the evaluation index of the Department of education. The establishment of evaluation index system should adhere to the principle of objectivity, integrity and testability.

Table 1. Expert judgment Basis

\begin{tabular}{|c|c|c|c|}
\hline \multirow{2}{*}{ Evaluation factors } & \multicolumn{3}{|c|}{ Influence degree } \\
\cline { 2 - 4 } & large & commonly & Small \\
\hline theoretical basis & 0.4 & 0.4 & 0.3 \\
\hline practical experience & 0.4 & 0.3 & 0.3 \\
\hline popularity & 0.4 & 0.1 & 0.1 \\
\hline first impression & 0.3 & 0.2 & 0.3 \\
\hline
\end{tabular}

The principle of objectivity refers to the establishment of the index system of scientific, rigorous, objective and credible, in line with the actual can accurately reflect the true level of evaluation. Holistic principle refers to the ideological and political education evaluation index system as a system to look at, should maintain its integrity, and there is no omission to reflect the goals should be achieved. The principle of measurement is that the evaluation object can be measured accurately, and it can be operated. In view of the thought political education content of performance evaluation of the complexity and fuzziness, the thoughts and ideas of the comprehensive study of the aforementioned scholars, using Delphi method in a more extensive and comprehensive perspective of College Students' Ideological and political education evaluation system design for the three levels of evaluation index system.

Table 2. Authoritative Coefficient of Expert Consultation

\begin{tabular}{|c|c|c|c|}
\hline secondary indicators & $\begin{array}{c}\text { Judgment } \\
\text { coefficient }\end{array}$ & Familiar coefficient & weight \\
\hline A1 & 0.71 & 0.68 & 0.69 \\
\hline A2 & 0.71 & 0.69 & 0.68 \\
\hline A3 & 0.71 & 0.72 & 0.70 \\
\hline B1 & 0.74 & 0.69 & 0.69 \\
\hline B2 & 0.72 & 0.71 & 0.72 \\
\hline B3 & 0.67 & 0.64 & 0.68 \\
\hline C1 & 0.71 & 0.67 & 0.69 \\
\hline C2 & 0.72 & 0.69 & 0.62 \\
\hline C3 & 0.69 & 0.72 & 0.71 \\
\hline D1 & 0.67 & 0.73 & 0.68 \\
\hline D2 & 0.69 & 0.71 & 0.74 \\
\hline E1 & 0.70 & 0.69 & 0.69 \\
\hline E2 & 0.71 & 0.73 & 0.73 \\
\hline mean value & 0.70 & 0.70 & 0.74 \\
\hline
\end{tabular}

Indicators are selected and determined, after two rounds of questionnaire after the consultation, all the indicators of the importance of mean score of greater than or equal to 6.77 , coefficient of variation is less than or equal to 0.23 , feasibility of mean value is 
greater than or equal to 5.43 , coefficient of variation is less than or equal to 0.31 , according to the importance of the index number less than 6 and coefficient of variation greater than 0.45 and above to be deleted standard, no to delete the index. According to the results of the two expert consultations, the final determination of the first level indicators is 5, two indicators is 17 . According to the second round of consultation, the use of direct scoring method to calculate the weight of the one or two indicators, and comprehensive use of direct scoring method and hierarchical index weight calculation method to calculate the weight of the index.

Table 3. Feasibility Evaluation Results

\begin{tabular}{|c|c|c|c|c|c|}
\hline \multirow{2}{*}{$\begin{array}{c}\text { first-class } \\
\text { index }\end{array}$} & \multirow{2}{*}{$\begin{array}{l}\text { second-class } \\
\text { index }\end{array}$} & \multicolumn{2}{|c|}{ Importance evaluation } & \multicolumn{2}{|c|}{ Feasibility evaluation } \\
\hline & & mean value & $\begin{array}{c}\text { variation } \\
\text { coefficient }\end{array}$ & mean value & $\begin{array}{l}\text { variation } \\
\text { coefficient }\end{array}$ \\
\hline \multirow{3}{*}{ A } & A1 & 8.22 & 0.15 & 5.53 & 0.15 \\
\hline & A2 & 8.67 & 0.20 & 6.05 & 0.17 \\
\hline & A3 & 8.89 & 0.17 & 6.23 & 0.23 \\
\hline \multirow{3}{*}{ B } & $\mathrm{B} 1$ & 6.77 & 0.23 & 7.02 & 0.31 \\
\hline & B2 & 6.91 & 0.21 & 5.58 & 0.28 \\
\hline & B3 & 7.24 & 0.18 & 6.29 & 0.25 \\
\hline \multirow{3}{*}{$\mathrm{C}$} & $\mathrm{C} 1$ & 8.63 & 0.17 & 7.35 & 0.7 \\
\hline & $\mathrm{C} 2$ & 7.65 & 0.21 & 5.98 & 0.18 \\
\hline & $\mathrm{C} 3$ & 6.87 & 0.22 & 6.85 & 0.21 \\
\hline \multirow{2}{*}{$\mathrm{D}$} & D1 & 7.71 & 0.18 & 6.56 & 0.30 \\
\hline & D2 & 7.68 & 0.09 & 7.12 & 0.14 \\
\hline \multirow{2}{*}{$\mathrm{E}$} & E1 & 7.89 & 0.05 & 7.24 & 0.17 \\
\hline & E2 & 8.21 & 0.13 & 7.31 & 0.16 \\
\hline
\end{tabular}

\subsection{Evaluation System of Ideological and Political Education}

The results show that the ideological and political education investment and environmental indicators, including environmental indicators, internal environment, such as good cultural atmosphere and social environment; external environment, such as stability of the national environmental education and harmonious social atmosphere for public opinion. The evaluation system is shown in Table 4.

\section{Table 4. The Performance Evaluation System of Ideological and Political Education}

\begin{tabular}{|c|c|c|}
\hline Target layer & first-class index & second-class index \\
\hline \multirow{13}{*}{$\begin{array}{c}\text { Performance } \\
\text { evaluation index } \\
\text { of Ideological and } \\
\text { Political } \\
\text { Education }\end{array}$} & \multirow{3}{*}{ Policy implementation (0.25) } & Institutional settings $(0.35)$ \\
\hline & & Staffing $(0.35)$ \\
\hline & & Development planning $(0.3)$ \\
\hline & \multirow{3}{*}{ Subject of Education (0.15) } & Ideological Education (0.25) \\
\hline & & Political Education $(0.2)$ \\
\hline & & Humanities Education $(0.25)$ \\
\hline & \multirow{3}{*}{$\begin{array}{l}\text { Ideological and political } \\
\text { education process }(0.2)\end{array}$} & Systematic $(0.35)$ \\
\hline & & Scientific nature $(0.3)$ \\
\hline & & Creativity $(0.35)$ \\
\hline & \multirow{2}{*}{$\begin{array}{l}\text { Information system } \\
\text { construction }(0.15)\end{array}$} & $\begin{array}{c}\text { Information collection and } \\
\text { management }(0.5)\end{array}$ \\
\hline & & Information analysis $(0.5)$ \\
\hline & \multirow{2}{*}{$\begin{array}{c}\text { Environment construction } \\
(0.25)\end{array}$} & Internal environment $(0.25)$ \\
\hline & & External environment $(0.25)$ \\
\hline
\end{tabular}


College students' Ideological and political education performance evaluation is the realization of Educational Science and system, but also improve the ideological and political education theory system based. Thinking the correct evaluation of the performance of political education is education is an essential component, it reflects the for students to carry out ideological and political education actual effect, summing up experiences and lessons for further effective implementation of Ideological and political education work to lay a solid foundation, also provide the objective basis for the achievement of appropriate evaluation of education.

\section{Conclusion}

In accordance with the "big ideological and political education philosophy, every individual is the subject of an active, constantly in the transformation of the objective world and the subjective world practice. Therefore, ideological and political education practice education channels should also is rich and varied, who can carry out ideological and political education of social practice and a variety of activities, should the rational development and utilization. The thought political education, thought and political education practice activities include school social practice and a variety of campus activities, and integrate all the resources, can further enhance the quality and effectiveness of the ideological and political education. Teachers and students is the ideological and political education in Colleges and universities in two important subjective factors, it is necessary to give full play to teachers' leading role; but also arouse student's initiative and enthusiasm, broaden channels, the benign interaction between teachers and students, so as to realize the integration of teachers and students two surface resources.

The integration of explicit and implicit ideological and political education resources is an important measure to innovate the ideological and political education in Colleges and universities. From the perspective of explicit knowledge, mainly teachers to integrate teaching content, accurately and effectively deliver the information of Ideological and political education, to avoid repetitive and boring; from the perspective of tacit knowledge should be combined with the reality of the characteristics, through the innovation mode, the college students' rational and calm attitude towards national hot academic lectures, media literacy education and other media. Both inside and outside the practice is the important link of the ideological and political education of college students, campus rich and colorful community activities, thoughts, knowledge, interest and mass in one, is a good form of self-education of college students; School of social practice to become a kind of effective form of Ideological and Political Education, determine the relative personalized practice questions on the topic, in the forms and methods of investigation, strengthen to the students the basic knowledge training, enhance out school social practice attraction and effectiveness.

\section{Acknowledgements}

This research is supported by the university counselor's project in working research department of Shaanxi Province "Research on College students' belief education under the network environment" (2015FKT29).

\section{References}

[1] R. Khansa, "Teachers' Perceptions toward School Counselors in Selected Private Schools in Lebanon", Procedia - Social and Behavioral Sciences, vol. 185, (2015), pp. 381-387.

[2] C. Krstev and A. Trtovac, "Teaching Multimedia Documents to LIS Students", The Journal of Academic Librarianship, vol. 40, no. 2, (2014), pp. 152-162.

[3] S. Jian-hua and L. hong, "Explore the Effective Use of Multimedia Technology in College Physics Teaching", Energy Procedia, vol. 17, (2012), pp. 1897-1900. 
[4] R. A. Sabella, "School counselors perceived importance of counseling technology competencies", Computers in Human Behavior, vol. 26, (2010), pp. 609-617.

[5] Z. Huang and M. Benyoucef, "From e-commerce to social commerce: A close look at design features", Electronic Commerce Research and Applications, vol. 12, no. 4, (2013), pp. 246-259.

[6] C. Zhang and X. Chen, "Use of Multimedia in Gross Infective Pathogen Experimental Teaching", Procedia Engineering, vol. 37, (2012), pp. 64-67.

[7] N. R. Mastroleo and R. Turrisi, "Examination of posttraining supervision of peer counselors in a motivational enhancement intervention to reduce drinking in a sample of heavy-drinking college students", Journal of Substance Abuse Treatment, vol. 39, (2010), pp. 289-297.

[8] W. Dai and L. Fan, "Discussion about the Pros and Cons and Recommendations for Multimedia Teaching in Local Vocational Schools", Physics Procedia, vol. 33, (2012), pp. 1144-1148.

\section{Authors}

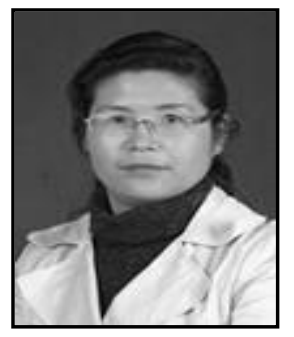

< chunyan ma > <1973.0513> <Xi'an,shaanxi PR China $>$

Current position, grade: instruction in sports and art department, Xi'an Physical Education University, shaanxi, China

Scientific Research: Her research interest fields include Philosophy, student management and educational science

Publication: more than 10 papers and one book

Experience: She has teaching 9 years, has completed five scientific research projects 